\title{
Toward the Integration of Theatre History and Affect Studies: Shame and the Rude Mechs's The Method Gun
}

\section{Citation}

Bernstein, Robin. 2012. Toward the integration of theatre history and affect studies: shame and the rude mechs's The Method Gun. Theatre Journal 64(2): 213-230.

\section{Published Version}

doi:10.1353/tj.2012.0037

\section{Permanent link}

http://nrs.harvard.edu/urn-3:HUL.InstRepos:11718219

\section{Terms of Use}

This article was downloaded from Harvard University's DASH repository, and is made available under the terms and conditions applicable to Other Posted Material, as set forth at http:// nrs.harvard.edu/urn-3:HUL.InstRepos:dash.current.terms-of-use\#LAA

\section{Share Your Story}

The Harvard community has made this article openly available. Please share how this access benefits you. Submit a story.

Accessibility 


\title{
Toward the Integration of Theatre History and Affect Studies: Shame and the Rude Mechs's The Method Gun
}

\author{
Robin Bernstein \\ "I slur all my words; in my affectedly casual manner I distort my way of \\ walking, theatrical triviality invades my being from all sides and takes me over. \\ Numb with shame, I hate my partner and I hate myself. I sit motionless for a \\ long time, and keep soothing myself with: 'Never mind, this is normal.'” \\ -Konstantin Stanislavski, Creating a Role ${ }^{1}$
}

In The Method Gun-a 2008 avant-garde theatrical piece created by Austin-based the Rude Mechanicals ("Rude Mechs"), written by Kirk Lynn and directed by Shawn Sides-a tiger (fig. 1) explains to the audience that the presence of a carnivorous beast improves any play, because at "any moment, any moment, I could run through and eat the person you are most bored with, or the person you are most interested in, or the person you are sitting next to. ${ }^{2}$ With this declaration, the tiger articulates a key idea in performance studies: that mortality and other forms of loss are engines that propel

Robin Bernstein is an associate professor of African and African American studies and of studies of women, gender, and sexuality at Harvard University. She is the author of Racial Innocence: Performing American Childhood from Slavery to Civil Rights (2011).

This essay grew out of a talk that the World Performance Project at Yale University commissioned as part of its research and publication initiative. I thank Joseph Roach, Emily Coates, and Kathryn Krier for inviting me to respond to the Rude Mechs's performance of The Method Gun in the 2010-11 "No Boundaries" series presented by the World Performance Project and the Yale Repertory Theatre. I also thank Madge Darlington and Kirk Lynn for discussing the Rude Mechs's process with me, and Paul Bonin-Rodriguez, Charlotte Brathwaite, Charlotte Canning, Sunder Ganglani, Christopher Grobe, Deborah Paredez, Rebecca Rossen, and especially Sara Warner and Theatre Journal's two anonymous readers for their comments and suggestions.

${ }^{1}$ Konstantin Stanislavski, Creating a Role, trans. Elizabeth Reynolds Hapgood (New York: Taylor \& Francis, 1989), 109.

${ }^{2}$ Several versions of The Method Gun have been performed and published. The show premiered in April 2008 at the Long Center for the Performing Arts Rollins Studio Theatre in Austin, Texas, and an early version of the script was published in Play: A Journal of Plays 4 (2010): 123-50. In March 2010, the Rude Mechs performed The Method Gun in the Humana Festival of New American Plays at the Actors Theatre of Louisville, and at that time, the show assumed its present form. The revised script is published in Humana Festival 2010, ed. Adrien-Alice Hansel (New York: Playscripts Inc., 2011), 161-204. A video recording of a performance of The Method Gun on 12 September 2011 at the Imago Theatre in Portland, Oregon, is now streaming online at $h t t p: / / w w w . o n t h e b o a r d s . t v / p e r f o r m a n c e / t h e a t e r /$ method_gun. This essay draws upon several sources of evidence: the published scripts of The Method Gun; a digitalrecording of the show as it was staged in March 2010 at the Actors Theatre, and a live performance I attended at the Yale Repertory Theatre in New Haven, Connecticut, on 23 February 2011. All quotations in this essay are transcribed from the digital recording of the performance at the Actors Theatre. 


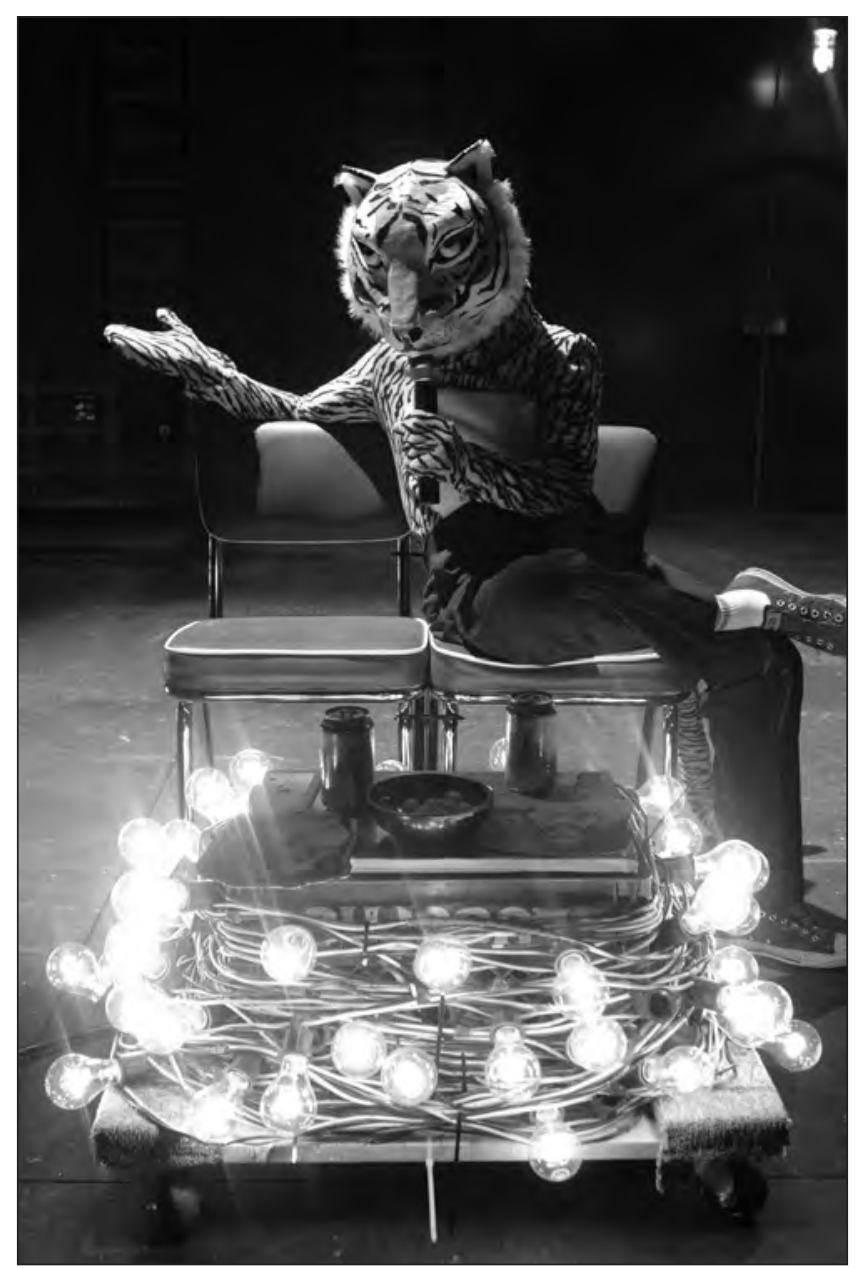

Figure 1. Promotional photograph of the tiger in The Method Gun (April 2008), Long Center for the Performing Arts, Rollins Studio Theatre, Austin, Texas. (Photo: Bret Brookshire.)

live theatre. "Of all the performing arts," Herbert Blau wrote in 1982, "the theater stinks most of mortality," because an actor "can die there in front of your eyes; is in fact doing so." ${ }^{3}$ A theatrical confrontation with death, simultaneously the worst-case scenario and a normal constancy for Blau, is, for Peggy Phelan, an ideal. In Phelan's view, theatre's power and significance lies in its ability to "respond to a psychic need to rehearse for loss, and especially for death." ${ }^{\prime 4}$ Marvin Carlson, Ann Pellegrini, Joseph Roach, and many other scholars have also argued, from different angles and by way of different evidence and methods, for death, loss, and ghostly presences as energetic components of live performance. The Method Gun's tiger and these scholars conceive live theatre's worst-case scenario—an onstage death—and best possibility—a profound

\footnotetext{
${ }^{3}$ Herbert Blau, Take Up the Bodies: Theater at the Vanishing Point (Champaign: University of Illinois Press, 1982), 83.

${ }^{4}$ Peggy Phelan, Mourning Sex: Performing Public Memories (New York: Routledge, 1997), 3.
} 
encounter with the living, dying human body—not as opposites, but instead as different points on a continuum.

The Method Gun, however, voices this truism ultimately to unravel it. Death is indeed a palpably literal risk in some forms of live performance, such as trapeze acrobatics or rodeo or in the work of some ordeal artists like Chris Burden or Marina Abramović. But in method acting - the specific mode to which Blau referred in the above quotation and which the Rude Mechs set in their cross-hairs-literal death is not, in fact, the worst-case scenario that weighs most heavily upon actors. In method-based realism and many other forms of Western theatre in the long twentieth century, the disasters that are most common and most dreaded relate not to death, but to shame. Actors routinely worry about forgotten lines, missed cues, missed marks, blank-outs, blackouts, stumbles and falls, giggle fits, costume rips, falling sets, broken props, problems with lights, projection, and sound, bad odors, bad writing, very bad writing, and every variety of excruciating acting. Actors are all too aware that audiences may laugh inappropriately, heckle, kvetch, cough, snore, fight, make out, eat, drink, drug, text, get bored, get offended, walk out quietly, or walk out unquietly. Or worst of all, an audience may be indifferent. In the four decades that I have attended and participated in theatre, I have witnessed every one of these shame-based calamities and experienced more than a few of them. But I have never seen anyone, onstage or in an audience, die.

As this essay will show, The Method Gun exposes shame as a crucial motor on par with death in much theatre (indeed, the theatrical power produced through shame and death often mingle and overlap, as the word "mortification" suggests). Shame is, as Konstantin Stanislavski notes in the epigraph to this essay, a "normal" presence in method and other forms of acting. The connection between shame and theatricality originated earlier: the word "shame" derives in part from the Gothic words Scham and skaman, which refer to covering the face-a performative gesture of shame and also a fundamentally theatrical action of masking, of producing that which is sham. ${ }^{5}$ The connections between shame and performativity are not only etymological, but also psychoanalytic: Eve Kosofsky Sedgwick, arguing after psychoanalyst Silvan Tomkins, makes a case for shame as a uniquely performative, or productive, affect, because shame, by forcing an individual into an awareness of herself as seen by others, produces a sense of individuality. ${ }^{6}$ Because of this link between shame and the

\footnotetext{
${ }^{5}$ Elspeth Probyn, "Writing Shame," in The Affect Theory Reader, ed. Melissa Gregg and Gregory J. Seigworth (Durham, NC: Duke University Press, 2010), 72; and Oxford English Dictionary, s.v. "shame."

${ }^{6}$ Eve Kosofsky Sedgwick, "Queer Performativity: Henry James's The Art of the Novel," GLQ 1, no. 1 (1993): 1-16, republished and expanded as "Shame, Theatricality, and Queer Performativity: Henry James's The Art of the Novel," in Sedgwick, Touching Feeling: Affect, Pedagogy, Performativity (Durham, NC: Duke University Press, 2003), 35-65. Sedgwick's point that shame, unlike embarrassment, is productive becomes clear in the following example. Two people experience the same event: their pants fall down. One person says, "Oh no, my pants fell down and everyone saw my butt; I'm so embarrassed," while the other says, "Oh no, my pants fell down and everyone saw what a clumsy idiot I am; I'm so ashamed." In the former case, the event is understood as regrettable though nonindividual: everyone has a butt, and occasional wardrobe malfunctions are nothing more than an unfortunate fact of life. In the latter case, the same event is felt, shamefully, both to reveal and to constitute- that is, to make, to perform in the Austinian sense- the essence of the person. Therefore shame does not simply reflect or express something in a constative mode, but produces subjectivity in a performative mode. The relationship between embarrassment and shame is complex and not one of contrast alone; my example is not intended to characterize fully the relationship between embarrassment and shame (for such an exploration, see Nicholas Ridout's subtle and fascinating "Embarrassment: The Predicament of the
} 
production of subjectivity, shame has become key to the fields of affect studies and, increasingly, performance studies.

Unlike the psychoanalytic and etymological approaches, however, The Method Gun connects shame not to performativity, but to theatre-and specifically to realism and avant-garde performance, including performance art, in the United States. ${ }^{7}$ Much performance art engages with shame as a subject (we might think, for example, of Robbie McCauley, Justin Vivian Bond and Kenny Mellman, Holly Hughes, or Lisa Kron, all of whom confront shame). ${ }^{8}$ The Method Gun nods to performance art's embrace of shame, while critiquing method-based realism as a historically located theatrical form that can intensify shame to the point of toxicity. The method actor risks categories of shame that her avant-garde sister does not: for example, the method actor might cry or kiss in ways that fail to register as "authentic" within the narrow criteria of realism. Conversely, the method actor might shame herself not by failing, but by succeeding in exposing her psychological truths and therefore her personal vulnerabilities. Furthermore, even while realism intensifies shame, it can cloak that structure, along with so much other theatrical scaffolding, behind the claim of authenticity. The problem with method-based realism, The Method Gun proposes, is that it demands that actors transcend shame by simultaneously baring their souls and decimating self-consciousness-and whenever that transcendence does not occur, method acting promotes shame about shame.

This vision of method acting is, of course, a caricature; it is a name assigned less to a historically located set of acting techniques than to a mode of snickering at actors' self-importance and self-decimation. The "method" for which the Rude Mechs's gun is a generalization, in which the teachings of Stanislavski are identical to those of Lee Strasberg, which are, in turn, indistinguishable from those of Sanford Meisner-and in this vision, Stella Adler, who defined herself largely in opposition to method acting, is reabsorbed into it and even becomes its champion. ${ }^{9}$

The Rude Mechs's staging of this method is not a distortion based on ignorance; to the contrary, it is a piercingly accurate portrait of a distortion that exists in the training experiences of many actors. The Method Gun critiques what Rude Mech Lana

Audience," in Stage Fright, Animals, and Other Theatrical Problems [Cambridge: Cambridge University Press, 2006], 70-95), but instead to use one point of contrast between shame and embarrassment so as to illustrate the specific ability of shame to produce subjectivization.

${ }^{7}$ Sedgwick used the word "theatricality" in her generative 1993 article about shame, but the essay focused on performativity, not theatrical practice - and most of the extensive scholarship indebted to Sedgwick has replicated this emphasis.

${ }^{8}$ See, for example, Robbie McCauley's Sally's Rape (in A Sourcebook of African-American Performance: Plays, People, Movements, ed. Annemarie Bean [London: Routledge, 1999], 246-64), Vicki Patraka's "Obsessing in Public: An Interview with Robbie McCauley" (in ibid., 219-45, esp. 221), and McCauley's unpublished 2011 show Sugar; Justin Vivian Bond and Kenny Mellman's Kiki and Herb: Coup de Theatre; Holly Hughes's Clit Notes (in Hughes, Clit Notes: A Sapphic Sampler [New York: Grove Press Books, 1996], 181-208); and Lisa Kron's 101 Humiliating Stories (in Kron, 2.5 Minute Ride and 101 Humiliating Stories [New York: Theatre Communications Group, 2001], 41-73).

${ }^{9}$ This homogenization of method acting is a common one; for critiques of this characterization of method acting, see David Krasner, ed., Method Acting Reconsidered: Theory, Practice, Future (New York: St. Martin's Press, 2000). Recently, J. Ellen Gainor and Rhonda Blair have shown, respectively, that many critiques of method acting respond to an oversimplified contrast between Stanislavski and Brecht, and that the critiques mischaracterize and undervalue bodily feeling. See Gainor, "Rethinking Feminism, Stanislavsky, and Performance," Theatre Topics 12, no. 2 (2002): 163-75; and Blair, "Reconsidering Stanislavsky: Feeling, Feminism, and the Actor," Theatre Topics 12, no. 2 (2002): 177-90. 
Lesley calls an "institutionalized misinterpretation" that results in "a mass of acting students literally performing their training on stage (as opposed to using that training as a tool to create their performance)." This "codification also results in a disturbing singular style among students today." 10 The Method Gun does not simply mock this homogenized method, but also grapples-at times parodically-with it. Specifically, The Method Gun explores how it feels to follow an acting guru, or any guru, who attaches the word "the" to a capitalized method or approach.

The Rude Mechs gathered and synthesized these feelings through an intense collective process involving several dozen theatre professionals from 2006 through 2007. Before this time, they had developed most of their works through collective conversation and improvisation among subgroups of the Rude Mechs. ${ }^{11}$ The Method Gun, however, greatly expanded this practice, to involve the full thirty-member company. The process of creating The Method Gun included a research trip to South America in 2006 and a week-long residency for twelve company members at the Orchard Project in upstate New York in 2007. Most significantly, the full company participated in a series of "lab nights" that ran weekly in the fall of 2007. In a lab night, any member of the company could lead an exploration of any idea, no matter how tenuously it seemed to be connected to The Method Gun. Kirk Lynn led a workshop, in which the company read essays by Susan Sontag and took photographs. Madge Darlington brought the company to a shooting range. And in a workshop that Darlington described as a breakthrough, Thomas Graves led an exploration of gurus, in which company members taught one another acting techniques in the style of a guru who had taught them. ${ }^{12}$ Through these free-associative, collaborative workshops, dozens of artists pooled their feelings and experiences of making theatre at the turn of the twenty-first century.

The Method Gun archives these historically located feelings. ${ }^{13}$ Specifically, I will argue, it archives shame associated with theatre-making - both realist and anti-realist-in the United States during the four most recent decades (and The Method Gun places experiences of those decades, which I refer to as "contemporary," in relation to method acting in the work of Tennessee Williams in the 1940s). As in any archive, the evidence it contains is partial, fragmentary, subject to multiple interpretations, and prone to distortion. Distortions in evidence do not de-legitimize any archive-if they did, no legitimate archives would exist. In the case of The Method Gun, distortions and missteps (including the caricature of method acting and, as I will discuss, an unthoughtful use of race-blind casting) are themselves artifacts, themselves illuminative and analyzable aspects of the archive.

As affect studies expands across disciplines and fields-from psychology to performance studies, queer theory, anthropology, sociology, literature, philosophy, art

\footnotetext{
${ }^{10}$ Lana Lesley, qtd. in Eliza Bent, "Madness in the Methods? Companies in New York and Texas Take on a Plethora of Techniques in Workshop Productions about Actor Training," American Theatre, January 2008, 137.

${ }^{11}$ See Kirk Lynn and Shawn Sides, "Collective Dramaturgy: A Co-Consideration of the Dramaturgical Role in Collaborative Creation," Theatre Topics 13, no. 1 (2003): 111-15.

${ }^{12}$ Madge Darlington, personal communication with author, 26 January 2012; see also Robert Faires, "Who Is Stella Burden, and Why Are They Saying Those Terrible Things About Her?" Austin Chronicle, 28 March 2008, available at http://www.austinchronicle.com/arts/2008-03-28/606144/ (accessed 26 February 2012).

${ }^{13}$ On affect and archives, see Ann Cvetkovich, An Archive of Feelings: Trauma, Sexuality, and Lesbian Public Cultures (Durham, NC: Duke University Press, 2003).
} 
history, and beyond-a problem has emerged: How can one historicize affect? How can one write a history of happiness and who, as Roland Barthes asked, will write a history of tears? ${ }^{14}$ In recent years, good answers to these questions have been offered by scholars like Sara Ahmed and Tom Lutz. ${ }^{15}$ Shame, however, has become increasingly central to the field of affect studies without significant historicization. ${ }^{16}$ The Method Gun suggests a new approach to this problem by revealing method acting as an intensifier as shame. Because method acting is historically located, that practice emerges as a valuable point of entry for scholars who wish to historicize shame-and the larger field of affect in which shame is crucial. Thus The Method Gun leads affect studies to theatre history and simultaneously reorients theatre studies toward shame, challenging theatre scholars to take shame as seriously as death.

\section{Loss and Shame in The Method Gun}

At the opening of The Method Gun the Rude Mechs members tell the audience that they received a grant to research the legendary acting teacher Stella Burden-her name a suspicious portmanteau of legendary acting teacher Stella Adler and not-gun-shy performance artist Chris Burden-who taught her "Approach" to a set of carefully selected acolytes. During a nine-year rehearsal period that began in the mid-1960s, the Stella Burden Company struggled to perform, with absolute authenticity and brutal emotional rawness, Williams's A Streetcar Named Desire without the characters Stella, Blanche, Stanley, and Mitch (an eccentric creative choice that the company never explains, but that has the effect of foregrounding minor characters like Eunice, Steve, "Negro Woman," and "Mexican Woman"). Burden's pedagogy was as extreme as her artistic vision: as one member of her company explains, Burden kept "a loaded gun in the rehearsal room to remind us we can kill each other. Or her. Or ourselves, I guess." She tutored her followers in "her desires," which she taught "one by one: to kiss strangers who look good to us! To laugh louder than most people can yell. HAH! And to use real beer in every rehearsal, no matter how early or what brand." Burden's acting exercises included "crying practice," in which members of the company wept as a kitchen timer ticked off the seconds, and "kissing practice," in which each member of the troupe kissed each other member to a metronomic beat. In 1972, when Burden abandoned her followers and disappeared without explanation to South America, the extreme rehearsals did not end: the company continued to practice Burden's Approach and labored to achieve the artistic vision in the absence of the guru.

The Method Gun stages the Burden Company's process of rehearsal, as well as its final production of Streetcar without the four lead characters; therefore The Method Gun

\footnotetext{
${ }^{14}$ Roland Barthes, A Lover's Discourse, in A Barthes Reader, ed. Susan Sontag (New York: Macmillan, 1983), 427.

${ }^{15}$ Sara Ahmed, The Promise of Happiness (Durham, NC: Duke University Press, 2010); Tom Lutz, Crying: The Natural and Cultural History of Tears (New York: W. W. Norton, 2001).

${ }^{16}$ Recent nonhistorical studies of shame include Elspeth Probyn, Blush: Faces of Shame (Minneapolis: University of Minnesota Press, 2005); Julien A. Deonna, Raffaele Rodogno, and Fabrice Teroni, In Defense of Shame: The Faces of an Emotion (New York: Oxford University Press, 2012); Phil Hutchinson, Shame and Philosophy: An Investigation in the Philosophy of Emotions and Ethics (New York: Palgrave Macmillan, 2008); and James David Velleman, "The Genesis of Shame," Philosophy \& Public Affairs 30, no. 1 (2001): 27-52. I do not mean to suggest that any of these works is wholly ahistorical, but rather that none holds the core goal of historicizing shame, or of using shame to ground the field of affect studies historically.
} 
contains two performances-within-performances, resulting in three concentric rings of narrative: fragments of Williams's script are contained in the Burden Company's rehearsal and performance of those fragmented scenes, which is, in turn, enclosed within the Rude Mechs's staging of that rehearsal process (a program for a 2011 production in New Haven dated these three rings by describing the setting of The Method Gun as "Yale Repertory Theatre, Present Day/Stella Burden's Company Rehearsal Room, 1970s/New Orleans, 1940s"). The rings are not always sharply delineated: it is often unclear whether an actor is speaking as a Rude Mech or as a member of the Burden Company. ${ }^{17}$

In each of these concentric rings, death and other forms of loss, especially violent loss, are crucial: the plot of Streetcar is launched by the suicide of Blanche Dubois's husband and climaxes with Stanley's rape of Blanche, followed by the loss of Blanche's already-tenuous grasp of reality; Burden abandoned her students after making them feel their own mortality, and hers, by rehearsing in the shadow of a loaded revolver; and the lethally titled Method Gun opens with a solemn warning to the audience not to interfere with the acts onstage, some of which are physically dangerous (a promise on which the performance does, at the end, make good).

But however important loss is to The Method Gun, shame is even more so. On the level of plot, Blanche's shame lies at the heart of Streetcar, the drama-within-the-rehearsalwithin-the-performance of The Method Gun. Blanche's debasement began, in the words of one of Burden's actors, when she "found [her husband] in bed with a man," told her husband that he "disgusted her," and he then "shot himself for shame." The widowed Blanche then engaged in behaviors that fueled "shameful stories" that, in turn, drove her to Stella and Stanley's apartment, where she is "ashamed to be."18 Shame then seeps beyond Williams's drama and into the Burden Company, which is haunted by a shameful question: What if their version of Streetcar, to which the actors have devoted nearly a decade, is "stupid" and therefore "everything we've done is nothing"? The company's nine-year rehearsal process satirically exaggerates the excess that underlies all theatrical production: live theatre is an extraordinarily labor-intensive form of art; theatre, by definition, almost could not possibly be worth it. It is that "almost" that enables theatre to exist—but that same "almost" installs the always-lurking, shameful suspicion that it might not be worth it, that the ratio of labor-to-reward is ridiculous, and makes all involved with theatre ridiculous.

\footnotetext{
${ }^{17}$ The Rude Mechs values this indeterminacy. In a talkback following the production at the Yale Repertory Theatre, the actors said that they wanted their audience to be no more than 80 percent sure of anything at any point in the show (they referred to this ideal as the "80/20 split"). In addition to deliberate ambiguity, chronological errors occasionally pockmark the show. For example, one actor prays: "God, please allow a couple of your rougher angels to rip a little hole in heaven and you use it to shit Tennessee Williams's ghost directly into our presence. . . . Please guide our company as we try to find our way without Stella. Amen." The reference to Stella clearly identifies the speaker as Koko, a member of the Stella Burden Company, rather than Lana Lesley, the Rude Mech actor who plays Koko. But the Stella Burden Company disbanded in the 1970s (and the scene in which the prayer is spoken is identified as 28 March 1975) and Williams died in 1983. Kirk Lynn confirmed in a personal communication with the author (on 8 April 2011) that this temporal confusion was an error, not an artistic choice. The Method Gun traffics in emotional, experiential, and physical precision-not chronological precision.

${ }^{18}$ The first quotation is from The Method Gun; the second from Williams, A Streetcar Named Desire (1947; reprint, New York: Signet, 1974), 70.
} 
Shame flickers, too, through the outermost ring of plot, through the Rude Mechs's claim to restage the practices of the renowned acting teacher Stella Burden and her followers. Upon first hearing of this premise, one might reasonably respond, as I did: "Who is Stella Burden?" No audience member has heard of this supposedly famous person, because Burden is fictitious. But in the time between encountering her name and realizing her fictitious nature-whether that "between" lasts a nanosecond or nine years-one is constructed as not-in-the-know, as a learner. The Method Gun reinscribes this identity in the opening moments when Graves, a member of the Rude Mechs, asks each member of the audience to remember "what it's like to be a student, at any point of your life, in need of guidance and discipline and encouragement." Thus the Rude Mechs pointedly defines the identity of "student" by lack and need, and not by other possible qualities like growth or community. The actors guide the audience through a meditation exercise, in which each person visualizes the one teacher who influenced her or him most. Each audience member is then instructed to write down that teacher's name on a slip of paper-an exercise, we are told, that Burden developed. As we hand in our papers, we are initiated into Burden's Approach; we perform our role as her students and we explicitly fuse that performance, in ways that might please Stanislavski, to our own memories and experiences of learning. Thus the Rude Mechs asks each of us to feel and to behave upon our ignorance, our neediness, our reliance on the kindness of teachers, our shame.

\section{The Theatricality of Shame, the Shame of Theatricality}

The mutual entanglement of shame and theatricality, which The Method Gun archives, depends on one particular property of shame: it is, paradoxically, a form of social isolation that is uniquely contagious. ${ }^{19}$ I opened this essay with a list of theatrical calamities, which included "every variety of excruciating acting." This phrase—cliché even-not only constitutes a negative aesthetic judgment, but it also reflects shame's contagious nature. The phenomenon of excruciatingly bad acting can exist for audience members (and not actors alone) only because shame is contagious: as Sedgwick has argued, to see a person who is (or in the witness's view should be) experiencing shame is to feel shame. Most or perhaps all affects are somewhat contagious: laughter can be infectious, for example, and depression is a downer. Sedgwick's point is that shame is uniquely defined by that contagiousness: one can be depressed in isolation, but shame is necessarily relational, in that it depends on one's failure, one's broken sociality, being witnessed, even if only by imagined others. Furthermore, shame is uniquely uncontrollable in its contagiousness-or as Kathryn Bond Stockton puts it, shame produces an "uncontrollable relationality" that queerly disrupts the boundary between individuals. ${ }^{20}$ When one names the emotional or physical pain of watching

\footnotetext{
${ }^{19}$ The idea that shame is a communicative negotiation of social isolation derives from Silvan Tomkins and Eve Kosofsky Sedgwick. According to Tomkins and other psychologists, the gestures associated with shame-eyes averted, head down-emerge in infants between their third and seventh months and under specific circumstances. This is the period when an infant learns to recognize its caregiver; it habitually looks at its caregiver, who looks back and thus closes a circuit of social communication. Sooner or later, however, the caregiver does not look back. When the circuit is broken, the infant averts its own eyes, hangs its head, and, psychologists theorize, forms shame. Shame is thus both a result of broken communication and is itself a form of communication-of meaningful gestures, of affect. See Sedgwick, "Shame, Theatricality, and Queer Performativity," 36-37; and Sedgwick and Adam Frank, Shame and Its Sisters: A Silvan Tomkins Reader (Durham, NC: Duke University Press, 1995), esp. 133-78.

${ }^{20}$ Kathryn Bond Stockton, Beautiful Bottom, Beautiful Shame: Where "Black" Meets "Queer" (Durham, NC: Duke University Press, 2006), 16.
} 
whatever one considers to be bad acting, then, one describes the common experience of an audience member viscerally "catching" an actor's shame.

To attend live theatre is to risk this agony, to sign onto what might be understood as a shame-contract. Actors agree to be vulnerable onstage, to expose their bodies in acts, such as crying, kissing, or sword-swallowing, that they might not otherwise perform publicly. ${ }^{21}$ Method acting, as characterized (or caricatured) by the Rude Mechs, intensifies this shame-contract by disallowing distance between these acts and the actor; method acting, as many theatre practitioners understand and experience it, requires actors to expose their emotional lives, to manifest "authenticity" and therefore avow a personal connection to and investment in onstage behaviors. Actors routinely consent to display themselves metaphorically or literally nude, and audiences, in turn, agree to watch, to witness actors' vulnerability and experience the contagion of shame. To be an audience member is to accept shame, to agree to risk being mortified for and with the performers if things go wrong, and to risk sharing intimacy and vulnerability with them if things go right. Actors and audiences together accept these risks, hoping for what Stockton calls the "beautiful shame" of transcendent vulnerability and intimacy, while accepting the possibility of excruciating shame-and these pervasive possibilities keep shame present as potential, even as actors and audiences work together to keep it at bay.

Performance artist, director, and author Neil Bartlett observes in usefully close detail his own experience of the shame-contract that underlies so much theatrical performance. "There are moments" when one is onstage, he notes,

when you have an absolutely concrete sense of negotiating with the audience around the issue of shame, when you know you are about to do a shameful action. This happens microscopically, from second to second, in the performance-and this goes for singing a song or doing a drag number at a benefit or performing a performance-art monologue-when you say to the audience, or you imply by the way you prepare to perform something, "I am now going to do something that I know you do not want to watch me do, I am going to go too far, I'm going to embarrass you, because I'm doing something shameful." For instance, I'm going to be too effeminate, I'm going to be too loud, I'm going to be too obscene. Or watch me, I'm being too tender, I'm being too sincere-I'm sorry but I'm going to talk not dirty for a moment. I'm going to really get down to the common emotional reality of our shared experience. That can be very shaming. ${ }^{22}$

In this passage, Bartlett describes a distinct moment in which actors and audiences "negotiat[e]" a shame-contract that includes, but also exceeds that moment. Shame, for him, pools when a performer "go[es] too far" by being "too loud" or "too obscene," or when a performer is emotionally vulnerable-when he or she is "too tender" or "too sincere." Even as Bartlett describes the emergence of shame in specific circumstances, he simultaneously shows how shame exists beyond these moments, because the "negotia[tion] around the issue of shame," in his view, occurs before an actor performs a shameful act. In this pre-moment, "you [the actor] imply by the way you prepare to perform something" that shame is about to surface, for better or worse. The potential for audience members to participate in this negotiation of shame-before-the-shameful-act

\footnotetext{
${ }^{21}$ In some forms of live performance, such as puppetry, radio, or digital performance, an actor's body may not be visible onstage, but the body is still somewhere, executing motions in real time and therefore risking failure and shame.

${ }^{22}$ Neil Bartlett, "Plunge into Your Shame," in Gay Shame, ed. David M. Halperin and Valerie Traub (Chicago: University of Chicago Press, 2009), 341 (emphasis in original). I thank Stephen Low for drawing my attention to this quotation.
} 
exists, because the actor does not surprise the audience by artificially inserting shame into the theatrical event, but instead activates a contract that actors and audiences sign through the performative act of walking into the theatre space. ${ }^{23}$ That is to say, Bartlett can successfully alert his audience to an incipient moment of shame, because the terms of the theatrical contract allow that such a moment might occur.

This microscopic, second-to-second negotiation of a coming moment of shame occurs about halfway through The Method Gun in what might be called "The Dance of the Bad Rehearsal." This scene stages a lecture that Carl Reyholt, one of Burden's most devoted followers, gave in 1977 at Goucher College. Pompously, awkwardly occupying the role of teacher, Carl (played by Graves) describes one terrible rehearsal, in which "I never thought the play would be good in a hundred years, all our work is wasted, I [felt] stupid for even hoping I could make something good." On that occasion, Burden taught Carl that actors, unlike those in other professions, can at any time stop what they are doing and do something else instead. "For instance, right now," Carl tells his audience, "I wanna dance."

It is a sickening moment. Carl smiles coyly at his audience, simpers slightly. Is he really going to dance? After a hideous pause, however, he returns to his lectern and continues pontificating. But Carl continues to "imply," as Bartlett puts it, that a moment of shame is about to surface. Carl asks his audience a rhetorical question that falls pathetically flat, he flubs his lines, and then he removes his oversized necklace and eyeglasses to prepare for-yes-a dance. Lacking musical accompaniment, Carl hums tunelessly and sways. His stiff arms and clenched hands recall Pee-Wee Herman's, and audience members in both Louisville and New Haven tittered nervously.

But then something changes. The stiffness in Carl's arms becomes the isolated movements of pop-and-lock. The audience now sees Carl dancing awkwardly in 1977 and Graves in 2008 or 2011, revealing physical skill in hip-hop styles that did exist in 1977, but that were not then well-known among white people like Carl and Graves. Carl and Graves writhe together with perfect control. At the Louisville performance, Carl/Graves punctuated the dance by falling backward to land on the floor flat on his spine. This fall could, for a nonexpert, result in serious injury, but Carl/Graves sprang up unhurt. The audience not only clapped, but cheered - for Carl and his dance, and for Graves, who brought audience members to the edge of shame, but then seemed to deliver them from it with feats of physical virtuosity.

In the performance in Louisville in 2008, Carl/Graves cut off the cheering with a second segment in the dance. In this second part, he took from the lectern a roll of packing tape and danced with it, entangling himself in the tape. ${ }^{24}$ As the sticky tape increasingly constricted his movements the physical virtuosity became impeded, while the awkwardness remained unmitigated. ${ }^{25}$ In the first part of the dance, when Carl/

\footnotetext{
${ }^{23}$ In invisible theatre or other forms of street theatre, in which the audience does not choose to enter a theatrical space, the shame-contract is unsigned and shame may be imposed without consent. Much invisible theatre aims explicitly to shame an unwilling audience-as in a Boalian performance, in which a man threatens a woman on a bus, thus challenging unwitting audience members to intervene bravely or burn in shame at their inaction. Thus invisible theatre derives its power from noncontractual, rogue shame.

${ }^{24}$ Graves did not dance with tape the evening I saw The Method Gun in New Haven.

${ }^{25}$ Ahmed associates stickiness with disgust, but I would suggest that stickiness is also the texture of shame. Stickiness is, as Sedgwick describes shame, "both peculiarly contagious and peculiarly
} 
Graves fell backwards though escaped injury, he proposed that redemption or even escape from shame might be possible. The audience in Louisville rooted for him-and themselves - to defeat shame, and when Carl/Graves appeared to do so, when a mortifyingly awkward dance transformed into an expertly controlled awkward dance, the audience cheered not only for him, but also, I would argue, for the apparent collective triumph of actor and audience over shame. The second movement in the dance, however, gave lie to the first: shame reemerges and sticks, because it is a constitutive element of much contemporary live theatre.

Koko, another of Burden's actors, also negotiates her shame-contract, but unlike Carl, who brokers shame microscopically with his audience, she looks higher. "God," Koko prays, "help us do this idea [perform Streetcar without the main characters] even if it turns out to be something stupid or embarrassing or impossible. Help us to be emotionally honest, at least in little bursts for as long as we can handle it. . . Amen." 26 Like Bartlett, Koko describes shame not as a disaster to be avoided, but instead as a productive and necessary presence. She does not pray for the performance not to be "stupid or embarrassing or impossible"; rather, she prays for the performance to happen "even if" these calamities occur. Under the threat of a stupid, embarrassing, impossible performance, Koko tries to create "little bursts" of emotional honesty. These longed-for little bursts of authentic self-revelation are, she acknowledges, difficult to "handle" (as Bartlett puts it, "to really get down to the common emotional reality of our shared experience . . can be very shaming"). ${ }^{27}$ When Carl brings audience members to the brink of shame and then delivers them from it, only to mire himself again in awkwardness and when Koko asks God for the exquisite shame of emotional vulnerability without refusing the excruciating shame of publicly exposed stupidity they expose and accept the shame-contract.

Realism can intensify the stakes in the shame contract, because it demands not only that actors make themselves physically and emotionally vulnerable onstage, but that they do so while maintaining an appearance of reality. This intensification can consolidate through specific stage actions, such as crying. Crying is risky stage busi-

individuating" ("Shame, Theatricality, and Queer Performativity," 36). To feel something sticky is to become stuck to it, at least a little bit. Thus stickiness, by definition, interrupts individuality; it describes the state of converging with something that is not-you. Simultaneously, however, stickiness describes a state of attempting to isolate one's self from another, because one cannot feel stickiness unless one attempts to become unstuck (a person who sat, unmoving, in a pool of glue would not experience stickiness). Stickiness can also produce reflexive self-consciousness through an attempt to separate the self from the self, as when one's gluey fingers stick to each other. Thus stickiness entails a dialectical struggle between adhering to something and seeking freedom from it (even, and especially, when that something is the self), between contagion and isolation. Furthermore, to feel the texture of stickiness is to pay attention to one's own skin, to feel the relationship between one's skin and the sticky substance, to experience one's own skin as a problem, as something that will need to be washed or otherwise attended to. Thus stickiness, like shame, produces a self-conscious sense of the skin, the borders of the self. On stickiness and disgust, see Sara Ahmed, The Cultural Politics of Emotion (Edinburgh: Edinburgh University Press, 2004), 89-92. Ahmed also associates stickiness with race. See ibid. and Ahmed, "Declarations of Whiteness: The Non-Performativity of Anti-Racism," Borderlands e-Journal 3, no. 2 (2004), available at http://www.borderlands.net.au/vol3no2_2004/ahmed_declarations.htm (accessed 26 February 2012).

${ }^{26}$ Here, Koko uses the word "embarrassing" in a vernacular way, but the affect she describes is, in Sedgwickian terms, "shame."

${ }^{27}$ Bartlett, "Plunge into Your Shame," 341. 
ness, because to cry "realistically" an actor must make manifest a carefully rehearsed spontaneity. Crying that appears bogus is among realism's most excruciating calamities, and emotionally present tears can produce theatrical immediacy, intimacy, and vulnerability. Crying is therefore a high-risk/high-reward proposition for method actors and their audiences.

The Method Gun isolates crying for close study. Burden, the Rude Mechs claim, developed an acting exercise called "crying practice," which the Rude Mechs stage in The Method Gun (they also practice kissing and laughing-actions that, like crying, demand the appearance of spontaneity and can therefore bring actors to the edge of shame).$^{28}$ In the first crying practice, which occurs nine minutes into the show, the actors stand at the stage's edge, facing forward and outward. One actor sets a kitchen timer to three minutes and as the timer ticks, each actor induces him- or herself to cry. It is a long moment-three minutes exactly; it is hard to watch and is challenging both in the sense that it is difficult to endure, and in the sense that the actors are challenging - that is, daring - the audience to look back. Videotape of this crying practice in the Louisville production records some audience members alternating between watching the actors and looking away, and many members of the audience laughing with apparent nervousness. In the live production I attended at the Yale Repertory Theatre in New Haven, much tittering and coughing attended the beginning of crying practice. The audience then quieted, and scattered laughter broke out periodically. The laughter was not individually idiosyncratic, but instead coordinated in response to the actors' progressive grimacing: some members of the audience whispered to one another and pointed out individual actors' expressions. At one point, a belly laugh rolled through the audience. The end of crying practice occasioned no applause, just a wave of light laughter and, for me, relief.

Every time an actor is called upon to cry in live theatre the anxious question arises: What if I can't squeeze those tears out? Will I successfully produce tears this time, here and now, on cue? Direction to weep is a guarantor of performance anxiety; the question of tears-“Will I get them out?" — doubles upon patriarchy's definitional question, "Will I get it up?" The Method Gun answers both questions in a hilarious and absurd pun upon "performance anxiety": at one point in the show, each of the two male actors dances nude onstage except for a string that ties his penis to a bunch of helium balloons that keeps his penis aloft. It is a burlesque upon the fear of getting it up; the balloons guarantee that the penis is "up," but they also guarantee that the penis and its owner look ridiculous. As Graves commented on the balloon dance: "There's nothing left to this but the humiliation." ${ }^{29}$ The Rude Mechs's actors, as they get tears out and penises up, dramatize the impossibility of escaping shame and the productive value of accepting it. No matter what these actors do, shame remains unavoidable as their

\footnotetext{
${ }^{28}$ In Burden's "kissing practice," which the Rude Mechs stage along with "crying practice," actors kiss each other heterosexually and homosexually to an enforced rhythm. An earlier version of The Method Gun also included "laughing practice" (Lynn, personal communication with author, 8 April 2011). The palimpsest of laughing practice is legible in the Burden actors' self-consciousness about laughter: "I hate laughing onstage" one of Burden's actors says, and then executes a painfully fake laugh. Abruptly cued, context-less laughter appears throughout the Burden Company's Streetcar and therefore throughout The Method Gun. The Rude Mechs, then, singles out kissing, laughing, and crying for special scrutiny as potential intensifiers of shame.

${ }^{29}$ Faires, "Who Is Stella Burden, and Why Are They Saying Those Terrible Things About Her?"
} 
best-case scenario, worst-case scenario, and norm. Theatricality, The Method Gun ultimately suggests, is what can happen when contemporary performers and audiences come together, accept shame, and do not die.

\section{Shame and Race-Blind Casting}

The Method Gun exposes shame as the underlying condition for much contemporary theatre, and asserts the productivity of refusing to feel ashamed of that shame. In its treatment of race, however, the show inadvertently realizes precisely the danger that it warns against: shame that is shamefully denied, rather than productively negotiated. The light-skinned actors-both Burden's and the Rude Mechs's-engage in cross-racial performances, but remain conspicuously silent about doing so (in sharp contrast to the Burden actors' tendency to obsess over every other aspect, large and small, of their performances). ${ }^{30}$ This silence about race coagulates in The Method Gun as shame about shame. Unexamined cross-racial casting could (not unfairly) be interpreted as an artistic and political flaw in the show. As an archive of historicized theatrical feelings, however, The Method Gun also reveals an affective relationship between past practices of racial ventriloquism and contemporary practices of race-blind casting. Specifically, The Method Gun shows how race-blind casting can paper over the shame of racial ventriloquism.

In their various historical heydays, practices of racial ventriloquism (including, but not limited to, blackface minstrelsy) shamed people of color but were, for white people, shameless. It is in hindsight that racial impersonation became understood as white people's shameful legacy. The Rude Mechs and the Burden Company activate this historical shame when they cast white actors in Streetcar's roles of color. These actors play Negro Woman, Colored Woman, and Mexican Woman without racial stylization - that is, they play the roles as racially unmarked and therefore as if the characters were white. The white actors never comment on this linked cross-racial casting and emptying-out of racial stylization. Koko, played by nonblack actress Lana Lesley, urgently examines herself and her performance: she prays for shame, reaches desperately for theatrical honesty, and obsesses over every decision she has ever made. But at no point does Koko or Lesley say: "How am I supposed to play Negro Woman authentically? What does that even mean?"

I am not suggesting that the Rude Mechs should have attempted to "act black" or "act Mexican"; indeed, such a choice would have been politically and artistically wrongheaded. Instead, my point is that at the turn of the twenty-first century a white woman's performance of Negro Woman necessarily references a history of white racial masquerade that is now considered shameful. This shame, once restored and activated through performance, can only be expressed or repressed. The Rude Mechs chose the latter option. In The Method Gun, Burden's actors' self-involvement and self-examination stop abruptly before questions of whiteness; the Rude Mechs's actors are willing to display themselves dancing awkwardly, crying, flubbing lines, or even tethering their genitalia to balloons, but they never acknowledge their cross-racial casting or call attention to their own raciality. They never acknowledge themselves as white.

\footnotetext{
${ }^{30}$ As but one example of the Burden actors' fixation on large and small aspects of performance, Elizabeth Johns, a member of the Burden Company, says: "I hate the way my voice feels in my throat when I project. . . . I never know what to do with my hands. One day rehearsal was nothing but noticing how often I blink."
} 
This ashamed silence is historically specific, because the Rude Mechs's race-blind casting is part of a suite of nontraditional casting practices that gained prominence in the final decades of the twentieth century-practices that include the casting of people of color in roles originally written for white actors and, less frequently, the casting of white actors in roles of color (as when the white Patrick Stewart played Othello in an otherwise almost all-black cast). ${ }^{31}$ Two superb recent books-Angela Pao's No Safe Spaces: Re-casting Race, Ethnicity, and Nationality in American Theater and Brandi Wilkins Catanese's The Problem of the Color[blind]: Racial Transgression and the Politics of Black Performance-analyze these practices. ${ }^{32}$ Pao's and Wilkins Catanese's books go a long way toward historicizing contemporary cross-racial casting and the controversies it has generated or failed to generate, but neither attends in-depth to how colorblind casting feels. ${ }^{33}$ The Method Gun, in contrast, inadvertently archives shame associated with colorblind casting - not in what the characters say, but in what they do not say. This conspicuous silence exposes questions that have gone unasked in most studies of race-blind casting practices: How does such casting feel? How does race-blind theatre feel for diversely positioned actors and audience members? The Method Gun unintentionally raises these questions and thus hints at the expansive potential payoff of rethinking the history of cross-racial casting through affect.

Racialization, repressed and denied in the Rude Mechs's performance of the Burden Company's performance of Williams's play, crops up in an unexpected body: the tiger. This animal, by definition an unraced body, speaks in a heavy Spanish accent-a surprising (and unexplained) choice, because tigers are native to no Spanish-speaking part of the world. The Rude Mechs's actors take turns inhabiting the tiger suit, while E. Jason Liebrecht, visible from a corner of the stage, speaks the tiger's lines into a microphone. This ventriloquism racializes the tiger in a precise inversion of the process by which Negro Woman or Mexican Woman is emptied of racial specificity. Burden's actors obsess on and explore their shame regarding every aspect of their performance except the racial ones; thus they silence and deny the shameful history of racial ventriloquism. The anthropomorphic tiger, who claims implausibly to threaten literal death, does, in fact, bring onstage the real threat of repressed shame. Seemingly the emblem of the Rude Mechs's anti-realism, the tiger ironically realizes the danger that methodbased realism propagates and that the Rude Mechs decries: shame about shame. Its jaws sealed shut, the tiger performs the role of unmasticated shame-a cold lump of contemporary white shame that sits, unmoving and painful, in the belly of the show.

\section{Avoiding Death, Accepting Shame: The Closing Sequence of The Method Gun}

Even as The Method Gun meditates upon, engages with, catalogs, obsesses on, and embraces shame, the show fails to notice or examine racial shame-and this failure attests to the elusive power of shame itself. In Louisville, Carl/Graves danced this

\footnotetext{
${ }^{31}$ Angela Pao memorably called this 1997 Shakespeare Theatre Company production the "photonegative Othello"; see Pao, No Safe Spaces: Re-casting Race, Ethnicity, and Nationality in American Theater (Ann Arbor: University of Michigan Press, 2010), 104.

${ }^{32}$ Ibid., and Brandi Wilkins Catanese, The Problem of the Color[blind]: Racial Transgression and the Politics of Black Performance (Ann Arbor: University of Michigan Press, 2011).

${ }^{33}$ Wilkins Catanese tells one brief and evocative story about her own experience, as a black woman cast as Rosalind in Shakespeare's Twelfth Night, uttering the phrase "And I swear, by the white hand of Rosalind," but she does not describe her feelings in-depth; see Wilkins Catanese, The Problem of the Color[blind], 9-10.
} 
idea: shame returns and sticks. The Method Gun calls for actors not to deny or repress this shame (even as the show inadvertently demonstrates the danger of doing so), but instead for actors and audiences together to make space for shame, accept shame, and not die of it. The final ten minutes of the show translate this idea into visual spectacle.

The Method Gun's closing sequence of events begins when one of Burden's actresses, Elizabeth Johns, has an epiphany: "This is bullshit," she realizes. "The Approach is bullshit. And Stella is bullshit. And everything we've done is nothing." It is a moment of acceptance of extreme shame: the character has wasted nine years of her life for "nothing." After this epiphany, the stage lights dim slightly. There is a loud cracking noise, and four lanterns - which had been visible above the actors' heads throughout the show-suddenly fall, without apparent cause, to knee-level. Each lantern is attached to a heavy steel pipe. Falling lights present an all-too-real danger in theatre: they have killed or critically injured performers, as when singer Curtis Mayfield was paralyzed below the neck when lighting equipment fell on him in 1990. When the lanterns dropped without warning in New Haven, many members of the audience gasped at the danger.

The released lanterns and pipes begin to sway, pendulum-like, in swift arcs that slice from above the actors' heads to below their knees (fig. 2). The actors take turns pushing the lanterns so they do not lose momentum - or peril. Onstage, while the lanterns-and-pipes whiz within centimeters of actors' heads, the actors silently stage, as promised from the beginning, the entirety of Streetcar without the characters Stella, Stanley, Blanche, and Mitch. Every stage direction, every unit of blocking that we saw the Burden Company rehearse, is exactly repeated with the crucial addition of four, then five potentially lethal pendulums. At the performance in New Haven, a tense silence settled over the audience during the lanterns segment; when a lantern sliced especially close to someone's face, head, or spine, gasps broke out.

Because the lanterns segment restages blocking from Streetcar and from The Method Gun, the scene melts together the Burden Company's method-based realism and the Rude Mechs's alienation effects to produce highly precise, dangerous, Meyerholdian biomechanics that activate emotion through physical exercises. In this melting and reformation, shame recedes and the threat of literal death fills the theatre. Shame does not disappear, however; to the contrary, it is Elizabeth's acceptance of shame that launches the closing sequence, and shame remains present onstage throughout the lanterns segment, because what is being performed is, indeed, the Burden Company's $A$ Streetcar Named Desire. The death-defying biomechanics are not separate from Streetcar or The Method Gun; rather, the lanterns segment reassembles the elements of blocking we have already seen scattered throughout the show and recollects the packets of shame shed by the characters in Streetcar and by Burden's acolytes. Shame is everywhere, unavoidable, while death swings by, avoided-barely. In the lanterns segment, the Burden Company and the Rude Mechs together accept shame, risk death, and survive.

Throughout the show, the Rude Mechs claims to restage the Burden Company's process of rehearsal, and behind this conceit its own rehearsals remain invisible. When the lanterns begin to swing, however, it becomes clear that the Rude Mechs's movements were perfectly precise not only in the final segment, but throughout the show. Blocking that previously appeared rough — "rude" - is revealed as crystalline, and movements that seemed aimless or messy reemerge as virtuoso. This perfect pre- 


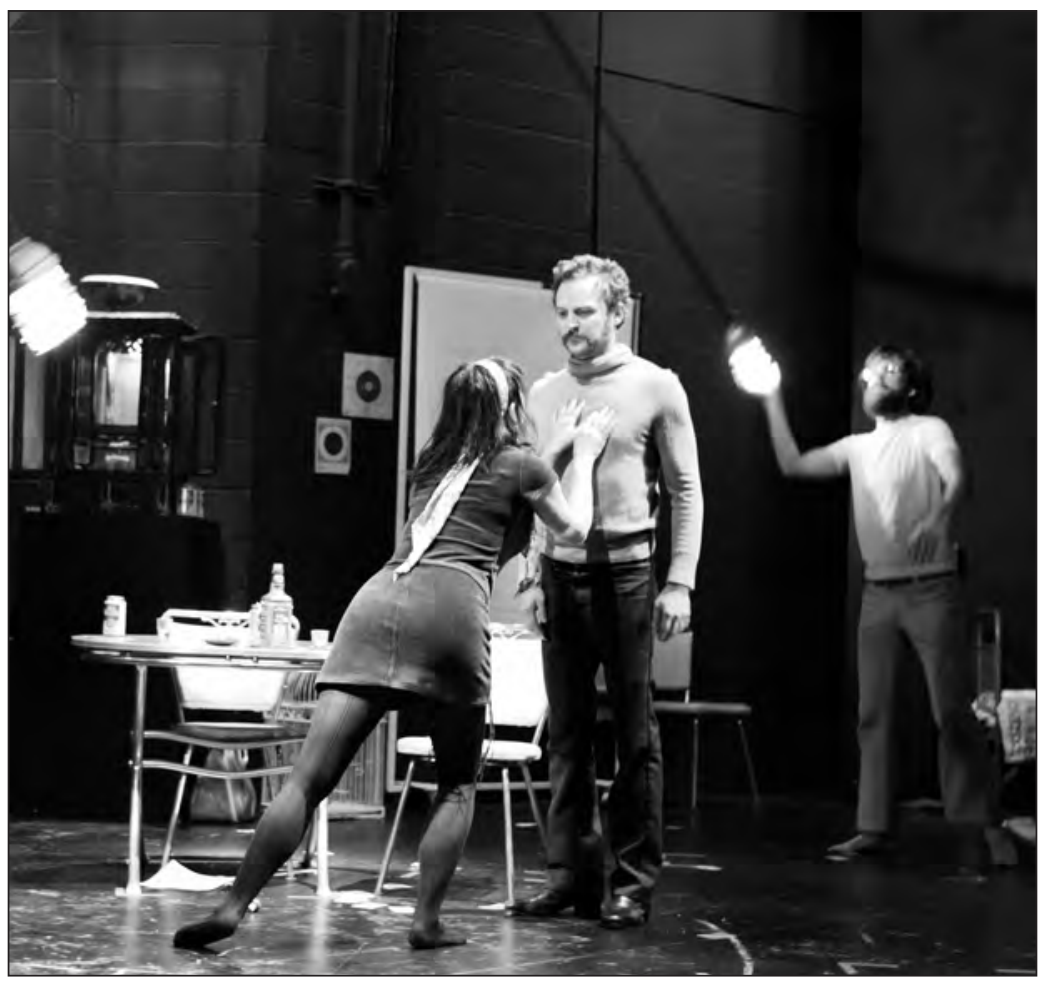

Figure 2. In the closing sequence of The Method Gun, the Rude Mechs perform all of A Streetcar Named Desire without the characters Stella, Stanley, Blanche, and Mitch, as pendulums swing by their heads. Left to right: Shawn Sides, Jason

Liebrecht, and Thomas Graves. Humana Festival of New American Plays (March 2010), Actors Theatre of Louisville. (Photo: Alan Simons.)

cision—upon which the actors' lives literally depend—reveals the Rude Mechs's own extreme process of rehearsal, without which the lanterns segment would have been intolerably dangerous. As they defy death, the Rude Mechs's actors become visible simultaneously as the Rude Mechs's and Burden's actors and Williams's characters. The three concentric rings of time and identity coalesce.

The Method Gun could have ended triumphantly after this biomechanical segment. Had the show ended there, the implication might have been that shame can and should recede, and that death really is the source of theatre's beauty and power. But it does not end there; instead, after the biomechanics end and literal death is no longer a palpable threat, Elizabeth quits the company and leaves with the tiger, and the remaining actors, for the second time in the show, practice crying - that exercise that plunges actors and audience into shame. But this second instance of crying practice did not, neither in Louisville nor New Haven, elicit the nervous giggles that the first crying practice provoked: in the former, the audience sat quietly, gazing back at the actors; and in New Haven, not one member of the audience laughed audibly during the second crying practice.

I think the audiences in Louisville and New Haven laughed at the first crying practice though not at the second, because the second almost immediately follows 
the biomechanical segment that reveals the Rude Mechs's physical precision. In this context, crying practice transforms into a biomechanical act that implicates the Rude Mechs as much as the Burden Company. Just as the Rude Mechs could not have evaded the lanterns without an intense and long rehearsal process, so also would the Rude Mechs's actors have been unable to make themselves cry onstage had they not practiced that physical act. In short, Burden's actors practiced crying, and the Rude Mechs must have practiced practicing crying. These acts are physically identical. In the second crying practice, then, the Rude Mechs's actors allow themselves and their processes of rehearsal to become visible and merge with those of the Burden Company. The actors refuse to refuse crying; they do not disavow the shame of the Burden Company.

In the closing sequence of The Method Gun, Rude Mechs's actors, along with Burden's students - all of us, as defined by the opening exercise of inscribing our gurus' names-accept shame and do not die of it. Burden herself tutored her followers in the art of living through shame and moving on without disavowing it: a letter that Burden left for one of her acolytes reads: "If you ever believed in something stupid—if you ever believed a guru who turned out to be a fraud-... you get another chance." ${ }^{34}$ The Rude Mechs's actors expose the shame-contract that underlies much contemporary live theatre, but they reject-shatter even - the clauses that method-based realism is felt to have added to that contract: clauses that seem to instruct actors to intensify shame and to deny doing so, to cloak shame behind a claim of authenticity, or to pursue a misguided fantasy of losing self-consciousness and shame by disappearing into character.

The Method Gun articulates the claim that death is the engine that drives live theatre, and literalizes and aestheticizes the threat of onstage death. But the show ultimately reveals death to be less menacing than shame. The plush tiger, which wears pants and resembles a sports mascot, destructively channels white shame though presents no physical threat. When Elizabeth quits the company, Carl attempts to shoot Burden's gun and discovers that the bullets are blanks—and we always knew that! "Of course it's fake," Elizabeth groans, exasperated. When Carl shoots, what is exposed is not the fakeness of the gun, but our knowledge of the fakeness of the gun, our knowledge of the lies behind realism's claims of authenticity. The gun onstage and in the title is a red herring; it asserts the possibility of death ("we could kill each other or ourselves"), but, in fact, the gun is as fake as the tiger- "of course." The literal threat and source of power, for actors and audiences equally, is shame.

In the epigraph to this essay, Stanislavski described himself as "[n]umb with shame," but the actors in The Method Gun are not. They feel the shame that powers so much contemporary avant-garde and realistic theatre; they negotiate it, show it second-bysecond, accept it (except when they repress it), practice it—and archive it. Or at least they archive the feelings of coping with, resisting, and surviving a generalized and much-ridiculed mode of self-obsessed actor training and performance often labeled "method acting." This experience of method acting is real, widespread, and historically located. So also is the other method acting-the one authored by identifiable individuals in specific historical and geographical contexts. The Rude Mechs and Stanislavski claim method acting (as each experiences it) as a site of special intensity in the production of shame. Both are correct-and for that reason, method acting pres-

\footnotetext{
${ }^{34}$ Bent, "Madness in the Methods?" 138. The quotation is from a fictitious letter that is partially read onstage at the end of The Method Gun.
} 
ents an extraordinary opportunity to historicize affect. I have argued throughout this essay that analysis of contemporary theatre demands consideration of shame no less than death. But the inverse is also true: because method acting is historically located and because shame is key to method-based realism and to affect studies writ large, theatre history of the long twentieth century constitutes a unique, rich, and vital site of inquiry into the history of affect. Theatre history needs affect studies-and perhaps even more so, vice versa. 